( Gi rask respons på artikler gjennom artikkelens kommentarfelt på tidsskriftet.no. Respons som er postet innen én måned etter at artikkelen er publisert, vurderes for publisering som Brev til redaktøren i papirutgaven.

Redaksjonen forbeholder seg retten til å foreta redaksjonelle endringer.

Forfattere av vitenskapelige artikler har tilsvarsrett, jf. Vancouver-gruppens regler.

\section{Nye møteplasser pă tvers av forvaltningsgrensene}

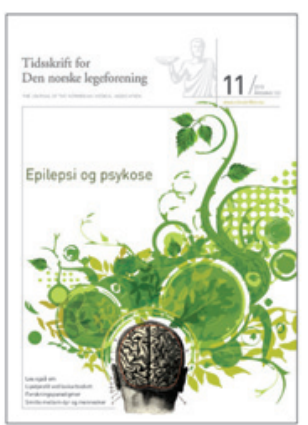

I Tidsskriftet nr. 11/2013 etterlyser Sigrun Møgedal et sterkere samarbeid mellom helseforvaltningen og utenriks- og bistandsfeltet (1). Global helse kan lære mye fra miljøfeltet, både når det gjelder integreringen av det nasjonale og det internasjonale perspektivet $i$ en nasjonal forvaltning, men også trekke lærdom fra de globale prosessene og de krevende forhandlingene. Et rent miljø og stabilt klima blir sett på som globale fellesgoder, som i praksis har vært gjenstand for harde globale forhandlinger. Fra miljøfeltet er det fruktbart å låne dette begrepet om globale fellesgoder. Helse kan også oppfattes som et globalt fellesgode, og understøttelse og vern av globale fellesgoder kan ikke vernes og støttes av bistand alene, men krever en samlet innsats på tvers av forvaltningsmessige skiller.

Innen utviklingspolitikken er det ikke lenger et like skarpt skille mellom giver- og mottakerland som før. Angola gir kriselån til Portugal, og flere andre afrikanske land har fått en stor middelklasse. Mottakerlandene er ikke lenger utelukkende mottakere, men også i økende grad selv givere og bidragsytere. Nigel Crisp, tidligere direktør for National Health Service i England, har pekt på at helsetjenester i lavinntektsland også kan vise til imponerende tiltak for innovativ organisering som senere er blitt etterliknet av høyinntektsland (2). Vi blir vitne til en kunnskapsoverføring den motsatte veien av det vi normalt er vant til, og nye tilnærminger til helse, helsetjenester og helseprofesjoner i lavinntektsland kan være like viktige som ideer fra rikere land (3). Det skarpe skillet mellom helseforvaltning og bistand, mellom nord og sør, er dermed ikke lenger like tydelig som før.

I den amerikanske globale helsestrategien tar man konsekvensen av at skillet mellom innenriks- og utenrikspolitikk ikke lenger er like skarpt, og man legger opp til en større samordning mellom akademisk medisin, helseforvaltning og det amerikanske utenriksdepartementet. Blant annet skal helsebyråkrater i det amerikanske føderale helsedepartementet på hospiteringsoppdrag for utenrikstjenesten for å sikre at kunnskap blir delt og erfaringer utvekslet for gjensidig nytte på tvers av forvaltningsgrenser. Samordning av global helsepolitikk på tvers av forvaltningen i USA forestås av et eget kontor for global helse. Akademisk biomedisin blir også trukket inn i samordningen. Den norske meldingen til Stortinget nr. 11 om global helse er ikke like konkret, og man trekker ikke opp, som Møgedal påpeker, noen konsekvenser for organisering og finansiering. Dette kan ha sammenheng med at norsk global helsepolitikk har vært personavhengig og i liten grad avleiret seg i form av konkret innenriks organisering og samarbeid.

Det er behov for å se nærmere på nettopp organisering og samarbeidsmønstre i den norske forvaltningen i form av for eksempel konkrete partnerskap og møteplasser på tvers av forvaltningsgrensene. Dette kan flytte global helsepolitikk et skritt videre i Norge. Av den grunn er Møgedals innlegg viktig.

\section{Kjetil Bordvik}

kjetil.bordvik@getmail.no

Kjetil Bordvik (f. 1980) er m.phil. i medisinsk antropologi og arbeider for FNs befolkningsfond (UNFPA) i København.

Ingen oppgitte interessekonflikter
Litteratur

1. Møgedal S. Global helse er målet - er helsebistand svaret? Tidsskr Nor Legeforen 2013; 133: 1159.

2. Crisp N. Turning the world upside down: the search for global health in the 21st century. London: RSM Press, 2010.

3. The Global Health Strategy of the U.S. Department of Health and Human Services. www.globalhealth.gov/pdfs/Global\%20Health\%20Strategy.pdf (12.8.2013).

Dette er en redigert versjon av et innlegg publisert som rask respons på nett 13.6.2013. http://tidsskriftet.no/article/3018350/

\section{Helsebistand og helseutvikling}

I Tidsskriftet nr. 11/2013 skriver Sigrun Møgedal om helsebistand og helseutvikling (1).

Det er blitt vanskeligere, ikke lettere, å lage global helsekunnskap og sette den ut i livet. Dialogen mellom byråkrater og fagfolk er tynnet ut, og det er mest økonomer og vennene deres som får viljen sin, og som ofte tror dette er et spørsmål om incentiver. $O g$ kvinner fortsetter å dø til tross for den fine retorikken som skal bekjempe det.

Når de gamle koster i global helse går av her hos oss, er det nesten bare meg igjen som hever røsten for bedre faglig kvalitet på helsetjenester for de fattigste i de fattige landene. I de 20 årene jeg har vært her ved Universitetet i Oslo har vi ikke fått én eneste stilling til i global helse eller i feltet kvinners helse for den saks skyld - til tross for alle ordene.

NORAD har aldri tid til dyp faglig oppfølging. Utenriksdepartementet svarer oftest ikke på mail. Forskningsrådet snakker om vaksine. Alle er tilsynelatende svært travle. Fattigdommen, ressursmangelen og kunnskapstørken består. På landsbygda i Malawi og Gambia er det langt til kompetent livreddende hjelp for helt vanlige problemer.

Og jeg skal snart pensjoneres, jeg også. I juni hadde vi to disputaser i arbeidshelse fra Palestina, og tre disputaser - endatil av kvinner - om mødrehelse i Malawi. Er det noen interesse for dette? Ikke i stor grad i alle fall.

\section{Johanne Sundby}

johanne.sundby@medisin.uio.no

Johanne Sundby (f.1951) er professor I ved Seksjon for internasjonal helse ved Det medisinske fakultet, Universitetet i Oslo. Ingen oppgitte interessekonflikter.

\section{Litteratur \\ 1. Møgedal S. Global helse er målet - er helsebistand svaret? Tidsskr Nor Lege- foren 2013; 133: 1159.}

Dette er en redigert versjon av et innlegg publisert som rask respons på nett 14.6.2013. http://tidsskriftet.no/article/3018350/

\section{S. Møgedal svarer:}

Bordvik og Sundby illustrerer lederartikkelens hovedpoeng (1): Norge trenger å ta nye grep $\mathrm{i}$ arbeidet med helsebistand og global helse. Dagens helseutfordringer sprenger rammen for hva nasjonale helsemyndigheter, norsk utenrikspolitikk og norsk helsebistand kan mestre på hvert sitt ansvarsområde. Helsefremmende nasjonal og internasjonal politikk må ses i sammenheng og forankres bedre i kunnskap. 